J. Clin. Chem. Clin. Biochem.

Vol. 24, 1986, pp. 583-587

(C) 1986 Walter de Gruyter \& Co. Berlin $\cdot$ New York

\title{
Effects of Neuroleptic Phenothiazines on the Activities of Aminotransferases and $\gamma$-Glutamyltransferase in Serum and Liver
}

\author{
By Ivana Čepelak, K. Lipovac, Dubravka Juretić
}

Institute of Medical Biochemistry, Faculty of Pharmacy and Biochemistry, University of Zagreb, and

\author{
Zlatka Birek \\ Hospital for Psychiatric Diseases, Zagreb
}

(Received July 15, 1985/April 1, 1986)

Summary: Serum alanine aminotransferase, aspartate aminotransferase and $\gamma$-glutamyltransferase activities were monitored in psychiatric patients receiving normal doses of phenothiazine neuroleptics over a 30-day period. The first two enzymes showed slight initial increases and a subsequent return to normal, while the third showed a slight increase. In rats, dosage levels exceeding those used in human therapy produced much larger increases in the catalytic concentrations of all three enzymes in serum $(1.4,0.7$ and 0.5 above the control value, respectively), and somewhat smaller increases in the liver homogenates of these animals.

Wirkung neuroleptischer Phenothiazine auf die Aktivitäten von Aminotransferasen und $\gamma$-Glutamyltransferase in Serum und Leber

Zusammenfassung: In Seren von geisteskranken Patienten wurden die Aktivitäten von Aspartataminotransferașe, Alaninaminotransferase und $\gamma$-Glutamyltransferase während einer dreißigtägigen Therapie mit Phenothiazinen bestimmt.

Die Änderungen in den Aktivitäten aller drei Enzyme bewegten sich etwa in dem breiteren Grenzbereich der Referenzwerte.

Experimente mit Ratten und größeren Dosen von Arzneimitteln haben signifikante Änderungen in den Enzymaktivitäten gezeigt: die Aktivitäten von Aspartataminotransferase waren bis zu 1,4, von Alaninaminotransferase 0,7 und von $\gamma$-Glutamyltranșferase $0,5 \mathrm{mal}$ höher als die Referenzwerte.

\section{Introduction}

Most types of neuroleptic drugs presently available are known to produce unwanted side effects, some of them adverse, thereby greatly impairing the usefulness of these drugs. The side effects may be neurological, endocrinological, allergic and biochemical (1). In the particular, the phenothiazine neuroleptics, promazine and chloropromazine, reportedly cause aplastic anaemia, agranulocytosis and thrombocytopenia in some patients (2). At the same time the catalytic activity of enzymes might become affected, and these effects should be reflected by catalytic activities in serum. Increases of serum creatine kinase, aspartate aminotransferase, alanine aminotransferase, and alkaline phosphatase have actually been reported $(3,4$, $5)$. The mechanisms of action of phenothiazines in the source organ of serum enzymes, namely the liver, are not completely understood. It is assumed that these agents cause a swelling of liver tissue. As a consequence the canaliculi are compressed and the bile flow is reduced (6), but the effect might extend as far as cellular disruption. 
Neuroleptic phenothiazines lacking the chlorine atom are generally considered to be less toxic than their developmental predecessors. To check this claim we examined the effects of chlorine-free phenothiazines on alanine aminotransferase ( $L$-alanine: 2 -oxoglutarate aminotransferase, EC 2.6.1.2), aspartate aminotransferase ( $L$-aspartate: 2 -oxoglutarate aminotransferase, EC 2.6.1.1) and $\gamma$-glutamyltransferase $(\gamma$-glutamyl peptide: aminoacyl glutamyltransferase, EC 2.3.2.2) in patients treated with these drugs. The effects of doses higher than the therapeutic level were examined in animal experiments.

\section{Materials and Methods \\ Treatment and sampling, patients}

The sera were obtained from male psychiatric patients newly admitted to the ward showing no pathologic symptoms of the liver. Patients were immediately subjected to 30 -day treatment with daily doses of

promazine $^{1}$ ) (group I: $\mathrm{N}=8$ ), a combination of promazine and fluphenazine ${ }^{2}$ ) (group II: $\mathrm{N}=8$ ), and a combination of

promazine and levopromazine ${ }^{3}$ ) (group III: $\mathrm{N}=6$ ).

Individual doses applied intramuscularly were sized in accordance with the severity of the case. Blood was collected once daily, $24 \mathrm{~h}$ after dosing, for the first four days of treatment, then on days 7,14 and 30 , at 8 a. $\mathrm{m}$.

\section{Animal experiments}

Male Wistar rats, 30 days old, average weight $100 \mathrm{~g}$, were kept on a normal laboratory diet with free access to drinking water. Experimentals and controls were selected at random. The former $(N=10)$ were injected intramuscularly once a day with $1 \mathrm{ml}$ of an aqueous solution containing promazine $(11.4 \mathrm{mg}$ / $\mathrm{kg})$ and fluphenazine $(0.8 \mathrm{mg} / \mathrm{kg})$.

The latter $(\mathrm{N}=10)$ received the same volume of $0.15 \mathrm{~mol} / 1$ aqueous $\mathrm{NaCl}$ (physiological saline). On each of days 1,2 , and 7 , appropriate numbers of animals from either group were anaesthetized (ether) and killed. Abdomina were opened immediately, blood was drained from the umbilical vein, centrifuged at once, and the serum stored frozen until enzyme activity determinations. Livers were removed, washed three times with ice-cold saline in order to remove blood, then individually homogenized in $0.14 \mathrm{~mol} / 1(50 \mathrm{~g} / \mathrm{l})$ aqueous $\mathrm{KCl}$ with cooling (Ultra Turrax homogenizer, type TP 18-10 Janke and Kunkel GK) for 1 minute. Two $\mathrm{ml}$ portions of each homogenate were added $10 \mu \mathrm{l}$ of aqueous Triton X-100 (200 g/l) and left $30 \mathrm{~min}$ at $+4{ }^{\circ} \mathrm{C}$. The Triton-treated as well as untreated homogenates were centrifuged at $16000 \mathrm{~g}$ for $1 \mathrm{~h}$ at $+4^{\circ} \mathrm{C}$ (refrigerated MSE $2 \mathrm{~L}$ centrifuge), and the supernatants saved for enzyme activity determination. The Triton-treated samples showed the total enzyme activities, while the untreated samples revealed the activities of unbound enzymes.

1) 10-( $\gamma$-dimethylaminopropyl)-phenothiazine

2) $10-(\gamma-(N-\beta$-hydroxyethyl-piperazine)propyl)-2trifluoromethyl-phenothiazine

3) $L$-10-( $\gamma$-dimethylamino- $\beta$-methyl-propyl)-3-methoxyphenothiazine

\section{Methods}

Alanine aminotransferase and aspartate aminotransferase activities were determined according to the methods of Schmidt \& Schmidt (7). $\gamma$-Glutamyltransferase activities were determined according to the method of Szasz (8). An LKB 2086 MARK analyser was used for the alanine aminotransferase and aspartate aminotransferase determinations, spectrophotometric measurements of $\gamma$-glutamyltransferase were made with a Perkin-Elmer Model 139 UVVIS spectrophotometer.

Total protein concentrations in the supernatants of liver homogenates were determined according to Lowry at al. (9).

The Wilcoxon (10) statistical treatment was used in evaluating the animal experiments.

\section{Results}

The effect of drugs on enzyme activities in vitro was studied by using a serum pool to which the drugs had been added. No changes in enzyme activities were found.

\section{Effects in humans}

Up to the seventh day of treatment with promazine, serum aspartate aminotransferase activities in $60 \%$ of all patients slightly exceeded the average normal value (fig. $1 \mathrm{a}$ ). The corresponding percentage in group II patients was somewhat lower. In the course of further treatment (all groups) the altered activity of aspartate aminotransferase mostly returned to normal. Serum alanine aminotransferase activities were apparently unaffected throughout, by either of the three treatments, except for very rare slight increases in group II patients (fig. 1 b). Raised serum $\gamma$-glutamyltransferase levels were initially observed in about 0.37 above the control value of group I and group II patients, and somewhat later in those of group III (fig. $1 \mathrm{c})$. At the completion of treatment, $50 \%$ of all patients had $\gamma$-glutamyltransferase activities above normal. The time course of the $\gamma$-glutamyltransferase activity increase was always regular and uneventful.

\section{Effects in rats}

The first injection was followed by very marked increases in aspartate aminotransferase and alanine aminotransferase (1.4 and 0.7 above the control value), but not $\gamma$-glutamyltransferase activities. Thereafter the aspartate aminotransferase and alanine aminotransferase levels diminished gradually, but still remained above control values at completion of the treatment (day 7); a $\gamma$-glutamyltransferase increase $(0.5$ above the control value, $p<0.05)$ was observed only on day 7 (fig. 2). The $\gamma$-glutamyl- 
Fig. 1a

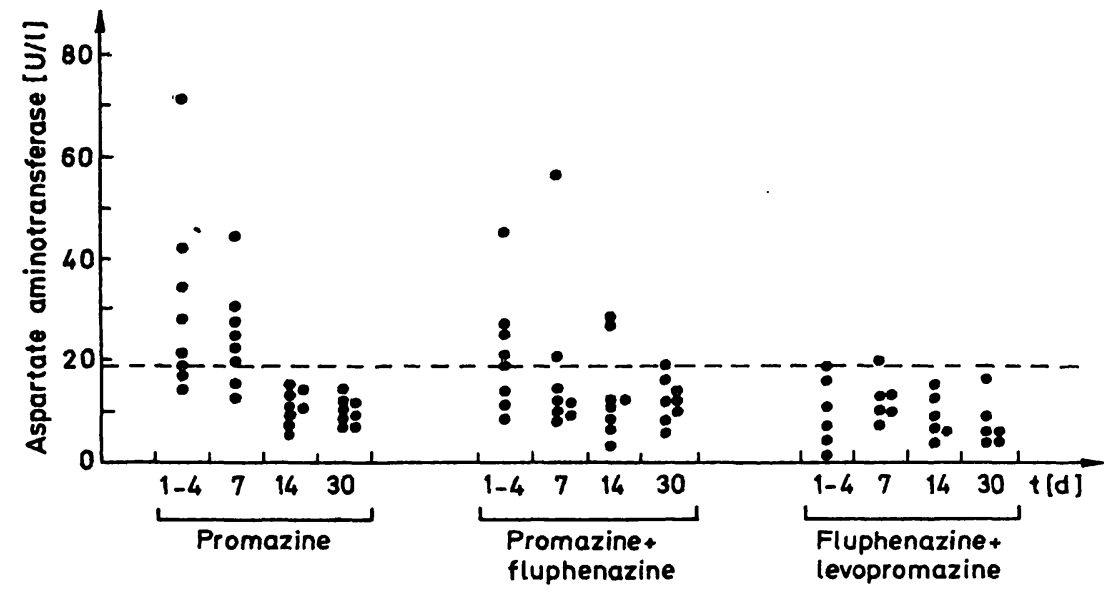

Fig. 1b

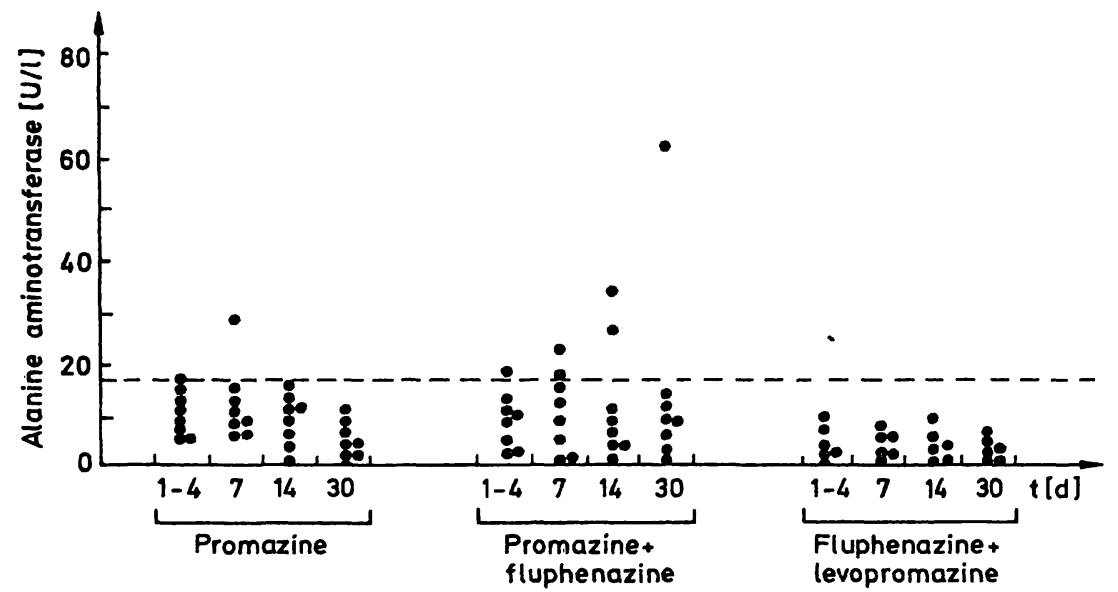

Fig. 1c

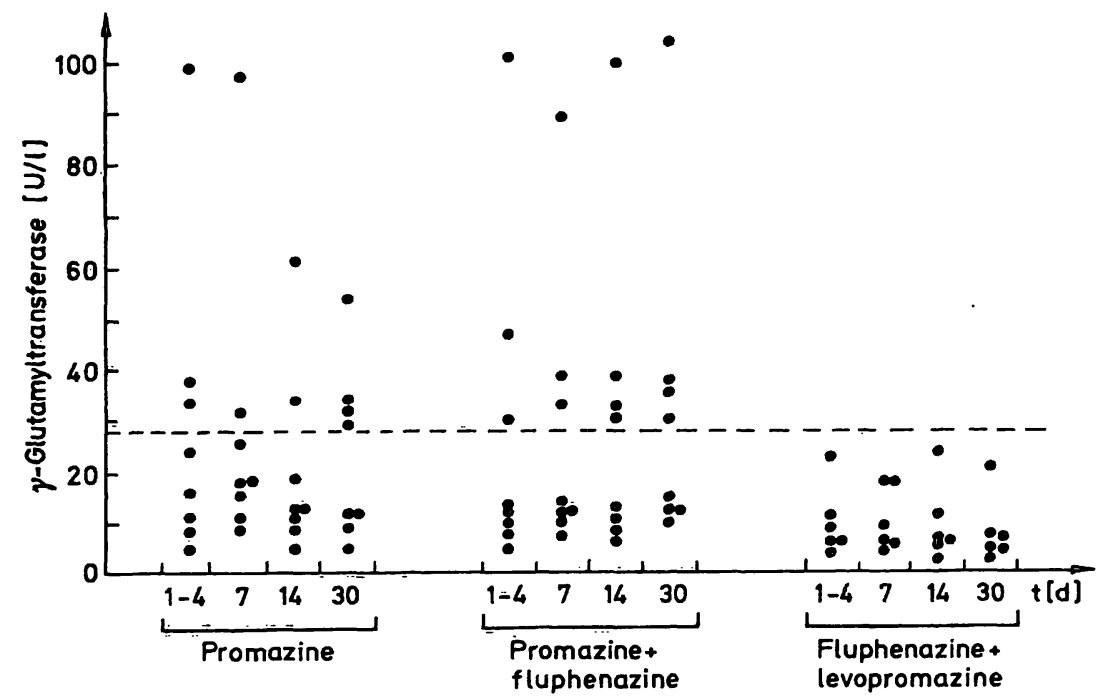

Fig. 1 a -c. Human serum transferase activities monitored in psychiatric patients under daily treatment with phenothiazine drugs. Frames a-c, aspartate aminotrảnsferase, alanine aminotransferase, $\gamma$-glutamyltransferase, respectively.

The broken line represents the upper limit of enzyme activities before therapeutical treatment.

transferase activity in the supernatant of the homogenate of the rat liver increased steadily throughout the treatment, whereas the activities of both alanine aminotransferase and aspartate aminotransferase increased for the first 3 days, but thereafter slowly decreased (fig. 3). With aspartate aminotransferase, the activities of total (unbound and bound) enzyme did not significantly change relative to that of un- bound enzyme. In contrast, the activity of total $\gamma$ glutamyltransferase changed significantly. The largest increase in total liver $\gamma$-glutamyltransferase followed the first injection ( 0.58 above the control value), then stabilized at about 0.3 above the control value for the rest of the treatment (fig. 4). The protein concentrations did not change significantly for the duration of an experiment. 


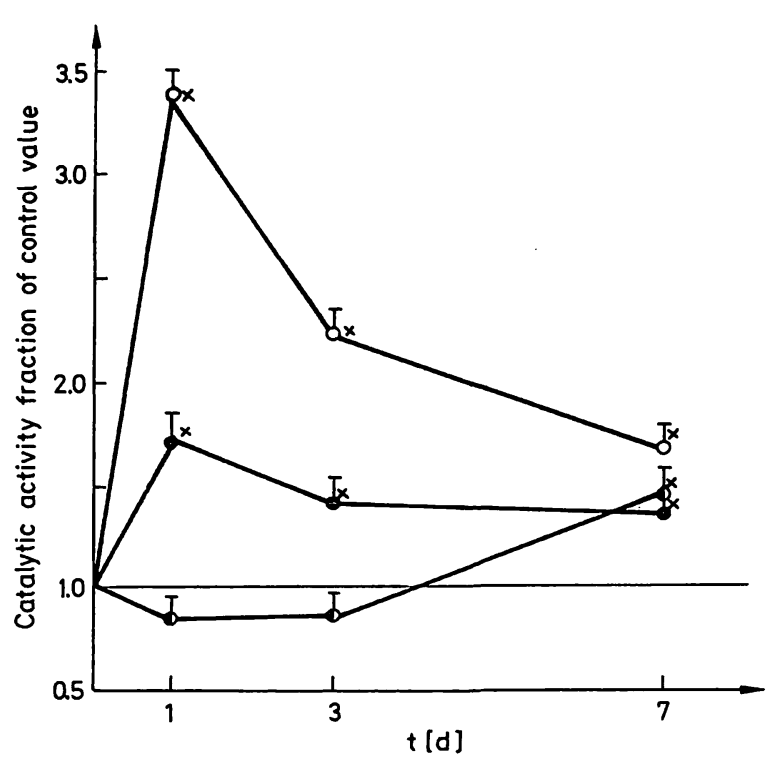

Fig. 2. Rat serum transferase activities monitored in animals receiving daily treatment with promazine and fluphenazine combined.

The enzyme activities are presented as catalytic activity fraction of the control value. The catalytic concentrations in the control group were $91 \pm 3.3 \mathrm{U} / 1$ for aspartate aminotransferase $(0-0), 9.35 \pm 0.5 \mathrm{U} / 1$ for alanine aminotransferase $(0-0)$ and $1.4 \pm 0.1 \mathrm{U} / 1$ for $\gamma$-glutamyltransferase $(\boldsymbol{O}-\mathbf{0})$, respectively; $\mathrm{p}<0.05$.

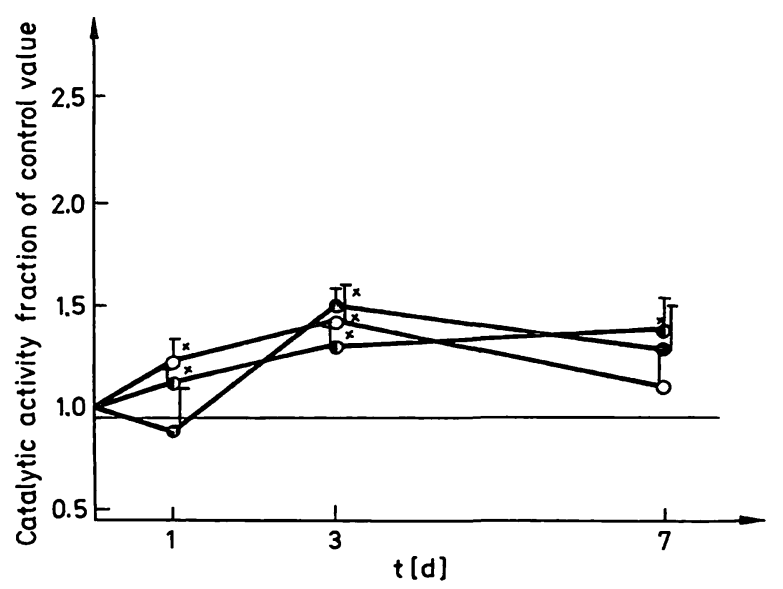

Fig. 3. Activities of non-bound transferase in supernatant of the homogenate of rat liver, following a single dose of promazine-fluphenazine combination. The enzyme activities are presented as catalytic activity fraction of the control value. The catalytic concentrations in the control group were $452 \pm 54.7 \mathrm{U} / \mathrm{g}$ protein for aspartate aminotransferase $(0-0), 50.1 \pm 4.3 \mathrm{U} / \mathrm{g}$ protein for alanine aminotransferase $(0-0)$ and $191 \pm 17.0 \mathrm{U} / \mathrm{g}$ protein for $\gamma$-glutamyltransferase $(\boldsymbol{O}-\mathbf{0})$, respectively; $\mathrm{p}<0.05$.

\section{Discussion}

The behaviour of serum enzyme activities in phenothiazine-treated patients (i. e. aspartate aminotransferase temporarily increased, alanine aminotransferase was mostly normal, and $\gamma$-glutamyltransferase increased occasionally) suggest that these drugs only

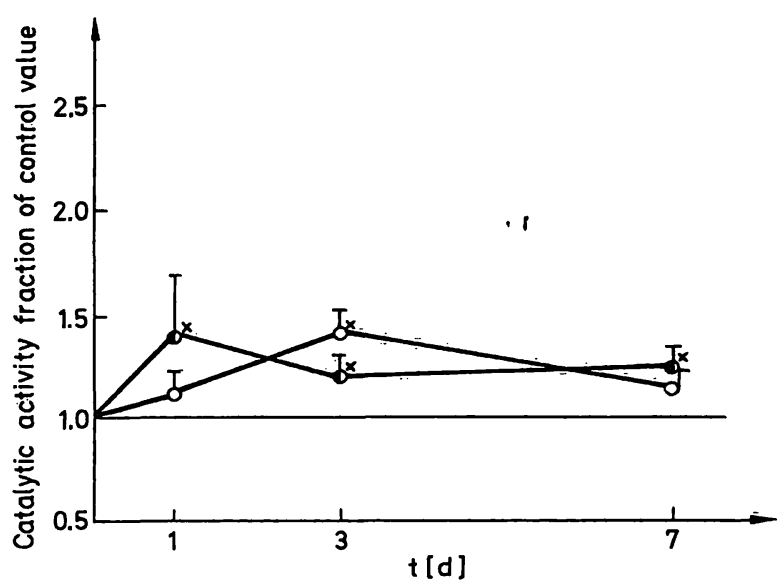

Fig. 4. Activities of total transferase in supernatant of the homogenate of rat liver, following a single dose of promazine-fluphenazine combination (bound enzymes were released by treating the homogenized tissue with Triton $\mathrm{X}-100$ ).

The enzyme activities are presented as catalytic activity fraction of the control value. The catalytic concentrations in the control group were $568 \pm 35.5 \mathrm{U} / \mathrm{g}$ protein for aspartate aminotransferase $(0-\bar{O})$ and $486 \pm 19.6$ $\mathrm{U} / \mathrm{g}$ protein for $\boldsymbol{\gamma}$-glutamyltransferase $(\boldsymbol{O}-\boldsymbol{Q})$, respectively; $\mathrm{p}<0.05$.

slightly effect the serum transaminase activities at the customary dosage levels. The absence of marked changes in serum enzymatic activity levels at the completion of a 30 day treatment indicates that these drugs may altogether be considered as non-toxic at moderate dosage levels. However, in critical phases of depression, elevated dosage levels and repeated dosing may be necessary. Such treatment should always be implemented with caution, and in particular, the use of phenothiazines at elevated dosage levels should be omitted in patients with manifest liver enlargement. Large doses of phenothiazines might cause cell damage. This assumption is confirmed by the outcome of our rat experiments. In the rat liver this effect resulted in a release of the intracellular enzymes, alanine aminotransferase, aspartate aminotransferase and $\gamma$-glutamyltransferase, into the extracellular space, and finally into blood plasma. The cell damage following the immediate impact of the drugs seems, however, to be stabilized subsequently, and even compensated for. As evidence of this, the serum activity either levels off with time ( $\gamma$-glutamyltransferase) or gradually reverts to normal, while the activities in liver homogenates change less markedly but in the same way.

The argument for compensation of cell damage holds only for the results observed with alanine aminotransferase and aspartate aminotransferase, but obviously not for those with $\gamma$-glutamyltransferase. The latter observations can, however, be explained if one re- 
members that $\gamma$-glutamyltransferase is partly localized on cell membranes. Therefore an additional mechanism of phenothiazine action must operate with regard to $\gamma$-glutamyltransferase. It is possible that these drugs induce de novo synthesis of this enzyme: $\gamma$-glutamyltransferase induction is a well known effect of drugs with various molecular structures $(11,12,13)$. Another possibility worth considering would be a membrane-solubilizing action whereby phenothiazine should cause a release of membranebound substances. A case in favour of this assumption has been reported for phenobarbitone $(14,15)$.

\section{Acknowledgement}

This study was supported by the Self-managed Community of Interest $\mathrm{V}$ for Scientific Research of the Socialist Republic of Croatia. The authors express their gratitude to Mrs. Blaženka Budisavljević for technical assistance.

\section{References}

1. Farmakoterapijski priručnik, gotovi lijekovi (1980) Zavod za organizaciju i ekonomiku zdravstva, Centar za lijekove, Zagreb.

2. Horler, A. R. (1978) In: Blood disorders; Textbook of adverse drug reactions, University Press, Oxford, p. 357.

3. Shay, H. \& Siplet, H. (1957) Gastroenterology 32, $571-591$.

4. Zelman, S. (1959) Amer. J. Med. 27, 768-729.

5. Young, D. S., Pestaner, L. C. \& Gilberman, V. (1975) Clin. Chem. 21, 187D.

6. Benkert, O. \& Hippius, H. (1976) In: Phychiatrische Pharmakotherapie, Springer-Verlag, Berlin, p. 109.

7. Schmidt, E. \& Schmidt, F. W. (1963) Enzymol. Biol. Clin. $3,1-6$.

8. Szasz, G. (1969) Clin. Chem. 15, 124-136.

9. Lowry, O. H., Rosenbrough, H. J., Farr, A. L. \& Randall, R. J. (1951) J. Biol. Chem. 193, 265-275.

10. Wilcokson, J. \& Walpore, R. W. (1969) In: Introduction to statistics, Collier McMillan International editions, p. 340.

11. Skillen, A. W. \& Pierides, A. M: (1976) Clin. Chim. Acta $72,245-251$

12. Herbeth, B., Bagrel, A., Dalo, B., Siest, G., Leclers, J. \& Rauber, G. (1981) Clin. Chim. Acta 112, 293-299.

13. Oldigs, H. D. \& Bartels, H. (1977) Klin. Wochenschr. 55, 86.

14. Tazi, A., Ratanasavanah, D., Galteau, M. M. \& Siest, G. (1979) Pharmacol. Res. Commun. 11, 211-220.

15. Cepelak, I. \& Straus, B. (1983) Acta Pharm. Jugosl. 33, $279-283$.

Dr. Ivana Čepelak

Institute of Medical Biochemistry

Faculty Pharmacy and Biochemistry

Domagojeva 2

YU-41000 Zagreb 
